\title{
Intracellular lithium and cyclic AMP levels are mutually regulated in neuronal cells
}

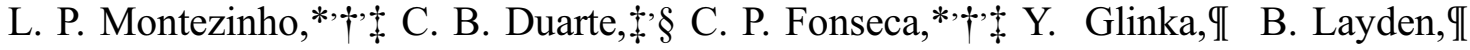 \\ D. Mota de Freitas, II C. F. G. C. Geraldes*†† and M. M. C. A. Castro*,† \\ *Department of Biochemistry, Faculty of Sciences and Technology, University of Coimbra, Coimbra, Portugal \\ $\dagger$ NMR Center, University of Coimbra, Coimbra, Portugal \\ \$Center for Neuroscience and Cell Biology, University of Coimbra, Coimbra, Portugal \\ §Department of Zoology, Faculty of Sciences and Technology, University of Coimbra, Coimbra, Portugal \\ IIDepartment of Chemistry, Loyola University of Chicago, Chicago, Ilinois, USA
}

\begin{abstract}
In this work, we studied the effect of intracellular $3^{\prime}, 5^{\prime}$-cyclic adenosine monophosphate (cAMP) on $\mathrm{Li}^{+}$transport in $\mathrm{SH}$ SY5Y cells. The cells were stimulated with forskolin, an adenylate cyclase activator, or with the CAMP analogue, dibutyryl-cAMP. It was observed that under forskolin stimulation both the $\mathrm{Li}^{+}$influx rate constant and the $\mathrm{Li}^{+}$accumulation in these cells were increased. Dibutyryl-cAMP also increased $\mathrm{Li}^{+}$ uptake and identical results were obtained with cortical and hippocampal neurons. The inhibitor of the $\mathrm{Na}^{+} / \mathrm{Ca}^{2+}$ exchanger, KB-R7943, reduced the influx of $\mathrm{Li}^{+}$under resting conditions, and completely inhibited the effect of forskolin on the accumulation of the cation. Intracellular $\mathrm{Ca}^{2+}$ chelation, or inhibition of $\mathrm{N}$-type voltage-sensitive $\mathrm{Ca}^{2+}$ channels, or inhibition
\end{abstract}

of cAMP-dependent protein kinase (PKA) also abolished the effect of forskolin on $\mathrm{Li}^{+}$uptake. The involvement of $\mathrm{Ca}^{2+}$ on forskolin-induced $\mathrm{Li}^{+}$uptake was confirmed by intracellular free $\mathrm{Ca}^{2+}$ measurements using fluorescence spectroscopy. Exposure of SH-SY5Y cells to $1 \mathrm{mM} \mathrm{Li}^{+}$for $24 \mathrm{~h}$ increased basal cAMP levels, but preincubation with $\mathrm{Li}^{+}$, at the same concentration, decreased cAMP production in response to forskolin. To summarize, these results demonstrate that intracellular cAMP levels regulate the uptake of $\mathrm{Li}^{+}$in a $\mathrm{Ca}^{2+}$-dependent manner, and indicate that $\mathrm{Li}^{+}$plays an important role in the homeostasis of this second messenger in neuronal cells.

Keywords: calcium, cAMP, forskolin, lithium, $\mathrm{Na}^{+} / \mathrm{Ca}^{2+}$ exchanger.

J. Neurochem. (2004) 90, 920-930.
Lithium salts have been used clinically for more than 50 years as mood-stabilizing agents in the treatment of bipolar disorder, a severe, chronic and often life-threatening disease that affects $1 \%$ of the world population (Goodwin and Jamison 1990). Plasma $\mathrm{Li}^{+}$concentrations in the range of $0.5-1.2 \mathrm{~mm}$ are correlated with the clinical efficacy in most patients, but toxic effects are often encountered when the plasma concentration exceeds $2 \mathrm{~mm}$. Despite the welldocumented therapeutic effectiveness of $\mathrm{Li}^{+}$, the biochemical basis of this $\mathrm{Li}^{+}$action is not completely understood (Manji et al. 1995; Jope 1999a).

It has been reported that $\mathrm{Li}^{+}$inhibits several cellular enzymes, most of them involved in signal transduction pathways, such as glycogen synthase kinase-3 $\beta$ (Williams and Harwood 2000; Ryves and Harwood 2001; Jope 2003), inositol monophosphatase (Allison and Stewart 1971; Hallcher and Sherman 1980) and adenylate cyclase (AC)
Received February 18, 2004; revised manuscript received April 14, 2004; accepted April 14, 2004.

Address correspondence and reprint requests to M. Margarida C.A. Castro, Department of Biochemistry, University of Coimbra, PO Box 3126, 3001-401 Coimbra, Portugal. E-mail: gcastro@ci.uc.pta

Abbreviations used: AA, atomic absorption; AC, adenylate cyclase; BAPTA-AM, 1,2-bis(o-aminophenoxy)-ethane- $N, N, N^{\prime}, N^{\prime}$-tetraacetic acid tetrakis (acetyoxymethyl ester); BSA, bovine serum albumin; $\left[\mathrm{Ca}^{2+}\right]_{\mathrm{i}}$, intracellular free $\mathrm{Ca}^{2+}$ concentration; cAMP, 3', $5^{\prime}$-cyclic adenosine monophosphate; $\omega$-CgTx GVIA, $\omega$-conotoxin GVIA; $\mathrm{db}$-cAMP, $\mathrm{N}^{6}, 2^{\prime}$-o-dibutyryladenosine $3^{\prime}, 5^{\prime}$-cyclic monophosphate; FCS, fetal calf serum; G-protein, guanine-nucleotide binding protein; KB-R7943, 2-[2-[4-(4-nitrobenzyloxy)phenyl]ethyl] isothiourea mesylate; $K_{\mathrm{d}}$, dissociation constant; $k_{\mathrm{i}}$, influx rate constant; KT-5720, 2-[1(3-dimethylaminopropyl)-1 $H$-indol-3-yl]-3-(1H-indol-3-yl) maleimide; MTT, 3-(4,5-dimethylthiazol-2-yl)-2,5-diphenyltetrazolium bromide; PKA, cAMP-dependent protein kinase; RO 20-1724, 4-(3-butoxy-4methoxybenzyl)-2-imidazolidinone; TTX, tetrodotoxin; VSCC, voltagesensitive $\mathrm{Ca}^{+}$channels. 
(Newman and Belmaker 1987; Mørk and Geisler 1989a). This inhibitory in vitro effect of $\mathrm{Li}^{+}$has been attributed to a competition between $\mathrm{Li}^{+}$and $\mathrm{Mg}^{2+}$ for $\mathrm{Mg}^{2+}$ binding sites in several biomolecules due to their similar physicochemical properties (Mørk and Geisler 1987a; Ramasamy and Mota de Freitas 1989; Mota de Freitas et al. 1994; Amari et al. 1999; Layden et al. 2000; Ryves and Harwood 2001). Several studies have demonstrated that $\mathrm{Li}^{+}$affects $3^{\prime}, 5^{\prime}$-cyclic adenosine monophosphate (cAMP) levels (Dousa and Hechter 1970; Mørk and Geisler 1987a,b; Newman and Belmaker 1987). The molecular mechanisms involved are still unclear, although the $\mathrm{Li}^{+}-\mathrm{Mg}^{2+}$ competition seems to participate in the inhibitory in vitro effect of $\mathrm{Li}^{+}$on AC activity (Newman and Belmaker 1987; Mørk and Geisler 1989a,b). $\mathrm{Li}^{+}$reduces cAMP production stimulated by agents operating downstream of the receptor [e.g. forskolin (Newman and Belmaker 1987; Andersen and Geisler 1984; Mørk and Geisler 1989a) and calcium-calmodulin (Mørk and Geisler 1987a,b; 1989c)] and decreases both receptor-mediated stimulation (Ebstein et al. 1980; Newman and Belmaker 1987; Mørk and Geisler 1989b; Carli et al. 1994) or receptor inhibition of AC activity in the rat brain (Ebstein et al. 1980; Newman et al. 1990). Moreover, $\mathrm{Li}^{+}$alters the activity of guanine-nucleotide binding proteins (G-proteins) regulating the activity of AC (Avissar et al. 1988; Masana et al. 1992). Two main types of G-proteins, $G_{s}$ and $G_{i}$, mediating stimulatory and inhibitory signaling, respectively, may account for both the antimanic and antidepressant therapeutic effects of $\mathrm{Li}^{+}$(Avissar et al. 1988; Manji 1992; Jope 1999b). Findings of high $\mathrm{G}_{\alpha \mathrm{s}}$ levels (Young et al. 1993; Friedman and Wang 1996) and increased forskolin-stimulated cAMP formation (Young et al. 1993) in cerebral cortical regions of post mortem brains from bipolar untreated patients support the hypothesis that a hyperactive $\mathrm{G}$ protein-coupled cAMP signaling system may be involved in the pathophysiology of this disease (Chang et al. 2003).

In human erythrocytes and in other cellular models $\mathrm{Li}^{+}$can partially replace $\mathrm{Na}^{+}$in a number of ion transport systems. These include the voltage-sensitive $\mathrm{Na}^{+}$channels (VSSC) (Ehrlich and Diamond 1980; Nikolakopoulos et al. 1998), the coupled active transport of $\mathrm{Na}^{+}$and $\mathrm{K}^{+}$(Beaugé 1978; Layden et al. 2003), the cotransport of $\mathrm{Na}^{+} / \mathrm{K}^{+} / \mathrm{Cl}^{-}$(Pandey et al. 1978), and the $\mathrm{Na}^{+} / \mathrm{Ca}^{2+}$ (Abajo et al. 1987; De la Fuente et al. 1996; Deval et al. 2002; Fonseca et al. 2004), the $\mathrm{Na}^{+} / \mathrm{H}^{+}$(Busch et al. 1995) and the $\mathrm{Na}^{+} / \mathrm{Li}^{+}$(Sarkadi et al. 1978) exchangers.

As cAMP levels have been suggested to be abnormal in bipolar patients, it is of interest to know whether this second messenger regulates $\mathrm{Li}^{+}$transport into neurons. Moreover, it is important to determine the effect of $\mathrm{Li}^{+}$on the homeostasis of intracellular cAMP levels. In this work we investigated the effect of intracellular cAMP on $\mathrm{Li}^{+}$uptake, at therapeutic plasma concentrations, in undifferentiated SH-SY5Y human neuroblastoma cells and in primary cultures of rat cortical and hippocampal neurons. This was assessed by using forskolin which is a diterpene derivative that activates $\mathrm{AC}$, raising cAMP levels in the cells (Seamon et al. 1981), and the cell membrane penetrating cAMP analogue, dibutyryl-cyclic AMP (db-cAMP). The pathways involved in $\mathrm{Li}^{+}$uptake, under resting or forskolin conditions, and the effect of $\mathrm{Li}^{+}$on the cAMP production in SH-SY5Y cells were also studied.

\section{Materials and methods}

\section{Materials}

The human neuroblastoma SH-SY5Y cell line was provided by Dr E. Stubbs Jr (Department of Neurology, Loyola University Medical Center, Chicago, IL, USA). Neurobasal medium, B27 supplement, gentamicin and trypsin (USP grade) were purchased from Gibco Invitrogen Corporation (Paisley, Scotland, UK). Fura-2/AM and Pluronic ${ }^{\circledR}$ F-127 were supplied by Molecular Probes (Leiden, the Netherlands) and RO-201724 and KT-5720 by Biomol (Plymouth Meeting, PA, USA). The $\left[8-{ }^{3} \mathrm{H}\right] \mathrm{cAMP}$ assay kit (TRK 432), BCA reagent and fetal calf serum (FCS) were obtained from Amersham Biosciences (Buckinghamshire, UK), Pierce (Rockford, IL, USA) and BioWhittaker Europe (Verviers, Belgium), respectively. Tetrodotoxin (TTX) and KB-R7943 were purchased from Tocris Cookson (Avonmouth, UK). All other reagents were from Sigma Chemical Company (Madrid, Spain) or from Merck (Darmstadt, Germany).

\section{Culture of the human neuroblastoma SH-SY5Y cells}

SH-SY5Y cells were grown in $75 \mathrm{~cm}^{2}$ polystyrene culture flasks, at $37^{\circ} \mathrm{C}$, in a humidified atmosphere of $5 \% \mathrm{CO}_{2} / 95 \%$ air. Cells were grown in Dulbecco's modified Eagle's medium (DMEM) buffered with $18 \mathrm{~mm} \mathrm{NaHCO}_{3}(\mathrm{pH} 7.35)$, and supplemented with $10 \%(\mathrm{v} / \mathrm{v})$ FCS, penicillin $(100 \mathrm{U} / \mathrm{mL})$ and streptomycin $(100 \mu \mathrm{g} / \mathrm{mL})$, and harvested by using a phosphate-buffer dissociation solution (in mM: 5.6 glucose, 58.4 sucrose, $137 \mathrm{NaCl}, 0.2 \mathrm{NaH}_{2} \mathrm{PO}_{4}, 0.2 \mathrm{KHPO}_{4}$ and $5.4 \mathrm{KCl}, \mathrm{pH}$ 7.4) (Stubbs and Agranoff 1993).

To determine intracellular $\mathrm{Li}^{+}$and cAMP levels, SH-SY5Y cells were seeded on six-well plates, at a density of $1.5 \times 10^{5} \mathrm{cells} / \mathrm{cm}^{2}$, and the experiments were carried out 3 days after the subculture. The intracellular free calcium concentration $\left(\left[\mathrm{Ca}^{2+}\right]_{\mathrm{i}}\right)$ was measured using SH-SY5Y cells cultured on $1 \mathrm{~cm}^{2}$ glass coverslips, at an initial density of $1 \times 10^{4}$ cells $/ \mathrm{cm}^{2}$, and the cells were used 2 days after the subculture. To test cell viability during incubation of $\mathrm{Li}^{+}$, the cells were seeded in 24-well plates, at a density of $1.5 \times 10^{5} \mathrm{cells} / \mathrm{cm}^{2}$, and were incubated with $\mathrm{LiCl}$ for $48 \mathrm{~h}$, after the subculture.

\section{Preparation of rat cortical neurons}

Primary cultures of cortical neurons were prepared from 15 to 16 days old Wistar rat embryos according to the method previously described (Hertz et al. 1989), with some modifications. Briefly, the neocortices were dissected and placed in $\mathrm{Ca}^{2+}$ - and $\mathrm{Mg}^{2+}$-free $\mathrm{Krebs}$ buffer (in mM: $120 \mathrm{NaCl}, 4.8 \mathrm{KCl}, 1.2 \mathrm{KH}_{2} \mathrm{PO}_{4}, 13$ glucose, 10 HEPES, pH 7.4) supplemented with $0.3 \%$ bovine serum albumin (BSA). After removing the meninges the neocortices were washed and incubated in $\mathrm{Ca}^{2+}$ - and $\mathrm{Mg}^{2+}$-free Krebs buffer containing $0.02 \%$ trypsin and $0.04 \%$ DNase $\mathrm{I}$, for $10 \mathrm{~min}$, at $37^{\circ} \mathrm{C}$. The digestion was stopped with $\mathrm{Ca}^{2+}$ - and $\mathrm{Mg}^{2+}$-free Krebs buffer containing $0.05 \%$ trypsin inhibitor (type II-S) and $0.004 \%$ DNase I, and the tissue was centrifuged at $140 \times g$ for $5 \mathrm{~min}$. After washing 
the pellet once more with $\mathrm{Ca}^{2+}$ - and $\mathrm{Mg}^{2+}$-free Krebs buffer the cells were dissociated mechanically. Cortical cells were cultured in Neurobasal medium supplemented with 2 mm L-glutamine, 2\% B27 supplement, penicillin $(100 \mathrm{U} / \mathrm{mL})$, and streptomycin $(100 \mu \mathrm{g} / \mathrm{mL})$. The cells were plated on poly D-lysine $(0.1 \mathrm{mg} / \mathrm{mL})$-coated multiwell plates, at a density of $0.15 \times 10^{6}$ cells $/ \mathrm{cm}^{2}$, and the cultures were maintained for 7 days, at $37^{\circ} \mathrm{C}$, in a humidified atmosphere of $5 \% \mathrm{CO}_{2} / 95 \%$ air.

\section{Preparation of rat hippocampal neurons}

The cells were dissociated from the hippocampi of 18-19 days old Wistar rat embryos, after treatment with trypsin $(2.0 \mathrm{mg} / \mathrm{mL}$, $\left.15 \mathrm{~min}, 37^{\circ} \mathrm{C}\right)$ and DNase $\mathrm{I}(0.15 \mathrm{mg} / \mathrm{mL})$ in $\mathrm{Ca}^{2+}$ - and $\mathrm{Mg}^{2+}$-free Hank's balanced salt solution (in mM: $137 \mathrm{NaCl}, 5.36 \mathrm{KCl}, 0.44$ $\mathrm{KH}_{2} \mathrm{PO}_{4}, 0.34 \mathrm{Na}_{2} \mathrm{HPO}_{4} .2 \mathrm{H}_{2} \mathrm{O}, 4.16 \mathrm{NaHCO}_{3}, 5$ glucose, 1 sodium pyruvate, 10 HEPES, $\mathrm{pH}$ 7.4). The cells were cultured in serum-free Neurobasal medium, supplemented with B27 supplement, glutamate $(25 \mu \mathrm{M})$, glutamine $(0.5 \mathrm{~mm})$ and gentamicin $(0.12 \mathrm{mg} / \mathrm{mL})$, as described previously (Brewer et al. 1993). The cells were plated on poly-D-lysine $(0.1 \mathrm{mg} / \mathrm{mL})$-coated multiwell plates at a density of $0.1 \times 10^{6}$ cells $/ \mathrm{cm}^{2}$. Cultures were kept for 7 days, at $37^{\circ} \mathrm{C}$, in a humidifed atmosphere containing $5 \% \mathrm{CO}_{2} / 95 \%$ air.

\section{Intracellular $\mathrm{Li}^{+}$measurements}

Before the experiments, the culture medium of SH-SY5Y cells was replaced by DMEM without FCS. When cortical and hippocampal neurons were used, the culture medium was not changed because it was free of FCS. Cells were preincubated for $15 \mathrm{~min}$ with the cAMP phosphodiesterase 4 selective inhibitor, RO-201724 (25 $\mu \mathrm{M})$ (Reeves et al. 1987). Then cells were incubated with forskolin $(10 \mu \mathrm{M}$; preincubation during $15 \mathrm{~min})$ or db-cAMP $(500 \mu \mathrm{M}$; preincubation during $30 \mathrm{~min}$ ). $\mathrm{LiCl}$ at $1 \mathrm{~mm}$ concentration was then added to the medium and, at the indicated time points $(5,15,30,45,60$ or $120 \mathrm{~min}$ ), the cells were washed with an ice-cold choline phosphate buffered solution (PBS) (in mM: 137 choline-Cl, $2.7 \mathrm{KCl}, 1.4$ $\mathrm{K}_{2} \mathrm{HPO}_{4}$ and $4.3 \mathrm{Na}_{2} \mathrm{HPO}_{4}, \mathrm{pH}$ 7.35) to remove extracellular $\mathrm{Li}^{+}$. The use of a Na${ }^{+}$-free choline-Cl medium prevents $\mathrm{Li}^{+}$efflux (Nikolakopoulos et al. 1998). The cells were lysed with $0.15 \mathrm{M}$ perchloric acid and the lysate was centrifuged at $15800 \times g$ (Eppendorf, 5417R), during $5 \mathrm{~min}$, at $4^{\circ} \mathrm{C}$. The supernatants were analyzed by atomic absorption (AA) spectrophotometry using a Perkin Elmer Analyst 100 spectrometer equipped with a flame source. The total intracellular $\mathrm{Li}^{+}$ concentrations, $\left[\mathrm{Li}^{+}\right]_{\mathrm{iT}}$, were calculated from the AA measurements using a calibration curve ( $\mathrm{Li}$ absorption versus $\mathrm{Li}^{+}$concentration). This calibration curve was obtained by measuring the Li absorption of three standard solutions, with three different $\mathrm{LiCl}$ concentrations: $0.1 \mathrm{~mm}, 0.2 \mathrm{~mm}$ and $0.4 \mathrm{~mm} \mathrm{LiCl}$. The kinetics of $\mathrm{Li}^{+}$influx in these cells was calculated using the equation:

$$
\left[\mathrm{Li}^{+}\right]_{\mathrm{iT}}=\left[\mathrm{Li}^{+}\right]_{\mathrm{i} \infty}\left[1-\exp ^{\left(-k_{\mathrm{i}}\right)(t)}\right]
$$

where $k_{\mathrm{i}}$ is the $\mathrm{Li}^{+}$influx rate constant, $\left[\mathrm{Li}^{+}\right]_{\mathrm{iT}}$ and $\left[\mathrm{Li}^{+}\right]_{\mathrm{i} \infty}$ are the total intracellular $\mathrm{Li}^{+}$concentrations at the different time points $(t)$ and when $\mathrm{Li}^{+}$concentration has reached a steady state, respectively.

\section{Measurements of $\left[\mathrm{Ca}^{2+}\right]_{i}$ in SH-SY5Y cells}

The SH-SY5Y cells were preincubated or not with the tested drugs, for the indicated periods of time. The cells were then loaded with $5 \mu \mathrm{M}$ fura-2/AM and $0.2 \%$ pluronic $\mathrm{F}-27$ in Krebs buffer (in mM: $132 \mathrm{NaCl}, 4 \mathrm{KCl}, 1.4 \mathrm{MgCl}_{2}, 1 \mathrm{CaCl}_{2}, 6$ glucose, 10 HEPES, $\mathrm{pH} 7.35$ ) supplemented with $0.1 \%$ fatty acid-free $\mathrm{BSA}$, for $40 \mathrm{~min}$, at $37^{\circ} \mathrm{C}$. A further incubation for $10 \mathrm{~min}$ in the same medium, without fura-2/AM and pluronic F-27, was made to obtain a complete hydrolysis of the probe. Coverslips were rinsed with Krebs buffer and mounted, with a special holder (PerkinElmer L2250008), in a temperature-controlled cuvette chamber. The fluorescence of fura-2-loaded cells was monitored using a computer-assisted Spex Fluoromax spectrofluorimeter, at $510 \mathrm{~nm}$ emission and double excitation at $340 \mathrm{~nm}$ and $380 \mathrm{~nm}$, using $5 \mathrm{~nm}$ slits. The calibration was made in the presence of $6 \mu \mathrm{M}$ ionomycin ( $\left.1 \mathrm{mM} \mathrm{CaCl}_{2} ; R_{\max }\right)$, at $800 \mathrm{~s}$, and $8 \mathrm{~mm} \operatorname{EGTA}\left(R_{\min }\right)$, at $1000 \mathrm{~s}$. The fluorescence intensities were converted into $\left[\mathrm{Ca}^{2+}\right]_{i}$ values using the calibration equation for double excitation wavelength measurements and the value of $224 \mathrm{~nm}$ was used for the dissociation constant $\left(K_{\mathrm{d}}\right)$ of the fura- $2 / \mathrm{Ca}^{2+}$ complex (Grynkiewicz et al. 1985):

$$
\left[\mathrm{Ca}^{2+}\right]_{\mathrm{i}}=K_{\mathrm{d}} \times\left(R-R_{\min }\right) /\left(R_{\max }-R\right) \times \mathrm{S}_{\mathrm{f} 380} / \mathrm{S}_{\mathrm{b} 380}
$$

where $R$ is the ratio of the fluorescence intensity of the probe at $340 \mathrm{~nm}, \mathrm{~F}_{340}$, and at $380 \mathrm{~nm}, \mathrm{~F}_{380} ; \mathrm{S}_{\mathrm{f} 380}$ and $\mathrm{S}_{\mathrm{b} 380}$ are the fluorescence intensities at $380 \mathrm{~nm}$ for the free and $\mathrm{Ca}^{2+}$-saturated dye, respectively.

\section{$\left[{ }^{3} \mathrm{H}\right]$ cAMP determination in SH-SY5Y cells}

The cAMP levels were measured in control and forskolin-stimulated cells, in the presence or absence of $1 \mathrm{~mm} \mathrm{LiCl}$ (preincubation times: 1, 24 and $48 \mathrm{~h}$ ). The cells were preincubated in the presence of RO-201724 $(25 \mu \mathrm{M})$ for $15 \mathrm{~min}$, and then further treated with forskolin $(10 \mu \mathrm{M})$, for $15 \mathrm{~min}$. The medium was then removed and the cells were scraped in $1 \mathrm{~mL}$ of $50 \mathrm{~mm}$ Tris/4 mM EDTA buffer, $\mathrm{pH} 7.35$, after washing with an ice-cold PBS solution. The extracts were boiled at $90^{\circ} \mathrm{C}$, for $4 \mathrm{~min}$, and centrifuged at $14000 \times g$ (Eppendorf, 5417R), for $5 \mathrm{~min}$, at $4^{\circ} \mathrm{C}$. Supernatants were used to quantify cAMP levels. Protein content in the pellets was determined by the bicinchoninic acid assay. Levels of cAMP in SH-SHSY cells were measured with an $\left[8-{ }^{3} \mathrm{H}\right] \mathrm{cAMP}$ assay kit (Amersham, TRK 432). Binding protein and $\left[8-{ }^{3} \mathrm{H}\right] \mathrm{cAMP}$ tracer were added to duplicated samples, which were kept cold $\left(2-8^{\circ} \mathrm{C}\right)$ for $2 \mathrm{~h}$. A charcoal suspension $(100 \mu \mathrm{L})$ was then added to the samples before centrifugation at $14000 \times g$ for $5 \mathrm{~min}$. A $200 \mu \mathrm{L}$ supernatant fraction of each sample was removed for scintillation counting. The cAMP levels were estimated by comparing the radioactivity of each sample with that of known standards.

\section{Assessment of cell viability}

The 3-(4,5-dimethylthiazol-2-yl)-2,5-diphenyltetrazolium bromide (MTT) assay was used to test cell viability after treatment of SHSY5Y cells with different concentrations of $\mathrm{LiCl}(0.5,1,5$ and $15 \mathrm{~mm}$ ) during $48 \mathrm{~h}$. MTT, when taken up by living cells, is converted from yellow to a water insoluble blue-colored precipitate by cellular dehydrogenases (Mosmann 1983). Cell cultures were incubated for $1 \mathrm{~h}$, at $37^{\circ} \mathrm{C}$, with a Krebs buffer containing MTT $(0.5 \mathrm{mg} / \mathrm{mL})$. The precipitated dye was dissolved by addition of $0.04 \mathrm{M} \mathrm{HCl}$ in isopropanol and the optical density was colorimetrically measured at $570 \mathrm{~nm}$, using an ELISA plate reader. 


\section{Data analysis}

Data are expressed as means \pm SEM and $p<0.05$ was considered significant. Statistical significance was determined by using analysis of variance (ANOVA), followed by Bonferroni's post hoc test, except in the kinetic studies where the Student's $t$-test was used.

\section{Results}

\section{Effect of intracellular cAMP on $\mathrm{Li}^{+}$uptake by neuronal cells}

To determine the effect of intracellular cAMP on $\mathrm{Li}^{+}$uptake by neuronal cells, forskolin was used as an activator of $\mathrm{AC}$ activity (Seamon et al. 1981), and the amount of $\mathrm{Li}^{+}$inside the cells was measured by AA spectrophotometry. The kinetics of $\mathrm{Li}^{+}$influx into SH-SY5Y cells was studied in the absence or presence of forskolin, under exposure to $1 \mathrm{mM} \mathrm{Li}^{+}$. This concentration is in the range of therapeutic concentrations used in the treatment of bipolar disease. Figure 1(a) shows that the $\mathrm{Li}^{+}$influx rate constant $\left(k_{\mathrm{i}}\right)$ value was higher in cells stimulated with forskolin than in the control situation $\left(k_{\mathrm{i}}=0.041 \pm 0.005\right.$ per min versus the control value $k_{\mathrm{i}}=$ $0.028 \pm 0.005$ per min; $p<0.05$ ). The total amount of $\mathrm{Li}^{+}$ accumulated by the cells was higher when the intracellular cAMP content was raised, particularly for $30 \mathrm{~min}$ incubation with $\mathrm{Li}^{+}(27.6 \pm 1.8 \mathrm{nmol} / \mathrm{mL}$ versus the control value (a)

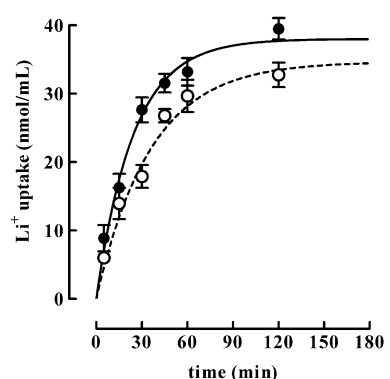

(b)

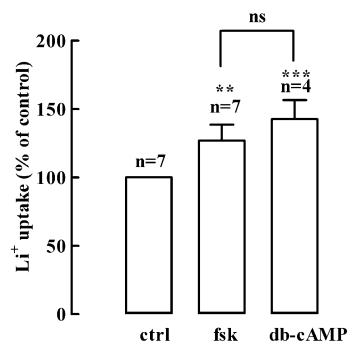

Fig. 1 Kinetics of $\mathrm{Li}^{+}$influx in SH-SY5Y cells, in the absence (O) (ctrl) and in the presence (-) of forskolin (fsk) (a). The cells were preincubated with RO-201724 (25 $\mu \mathrm{m})$, for $15 \mathrm{~min}$, and then with fsk $(10 \mu \mathrm{M})$, for $15 \mathrm{~min}$. LiCl at $1 \mathrm{~mm}$ concentration was then added to the medium and at 5, 15, 30, 45, 60 or 120 min the amount of $\mathrm{Li}^{+}$taken up by cells was measured by AA spectrophotometry. The rate constants obtained for $\mathrm{Li}^{+}$influx were $0.028 \pm 0.005$ per min (ctrl) and $0.041 \pm 0.005$ per min (fsk) $(p<0.05)$. Values are means \pm SEM of 4-20 independent experiments. (b) $\mathrm{Li}^{+}$uptake by $\mathrm{SH}-\mathrm{SY} 5 \mathrm{Y}$ cells pretreated or not (ctrl) with fsk (10 $\mu \mathrm{M} ; 15 \mathrm{~min})$ or db-cAMP $(500 \mu \mathrm{M}$; $30 \mathrm{~min}$ ), in the presence of RO-201724 and before incubation with $\mathrm{Li}^{+}$, for $30 \mathrm{~min}$. The total intracellular $\mathrm{Li}^{+}$was measured by AA spectrophotometry, as described in the methods section. Data are presented as a percentage of intracellular $\mathrm{Li}^{+}$content relative to the control. Values are means \pm SEM for the indicated number of independent experiments. ${ }^{\star \star} p<0.01 ;{ }^{\star \star \star} p<0.001$, significantly different from control; ns, not significant.
$17.9 \pm 1.7 \mathrm{nmol} / \mathrm{mL} ; p<0.01)$. In order to confirm that these effects were due to an increase in intracellular cAMP and not to a non-specific effect of forskolin, experiments with db-cAMP were performed. Figure 1(b) compares the effect of forskolin and db-cAMP on the uptake of $\mathrm{Li}^{+}$by the SH-SY5Y cells exposed to the cation $(1 \mathrm{~mm})$ for $30 \mathrm{~min} . \mathrm{Li}^{+}$uptake by cells incubated with forskolin and db-cAMP was not significantly different, but it was significantly higher than the control $[126.9 \pm 11.6 \%$ for forskolin $(p<0.01)$ and $142.6 \pm 13.9 \%$ for db-cAMP $(p<0.001)]$.

Similar results were obtained with rat cortical $[133.5 \pm 5.9 \%$ for forskolin $(p<0.01)$ and $154.0 \pm 9.3 \%$ for db-cAMP $(p<0.001)]$ and hippocampal neurons $[133.3 \pm 11.9 \%$ for forskolin $(p<0.05)$ and $141.4 \pm 6.9 \%$ for db-cAMP $(p<0.05)$ ] (Fig. 2a,b).

\section{$\mathrm{Li}^{+}$influx pathways in SH-SY5Y cells}

In order to investigate the transport pathways responsible for $\mathrm{Li}^{+}$uptake by SH-SY5Y cells, inhibitors or blockers of the main transport systems present in the plasma membrane of these cells were used, in control (Fig. 3) and forskolinstimulated cells (Fig. 4a,b). The amount of $\mathrm{Li}^{+}$taken up by the cells was determined by AA spectrophotometry after 30min exposure to $1 \mathrm{mM} \mathrm{Li}^{+}$. The contribution of VSSC, N-type voltage-sensitive $\mathrm{Ca}^{2+}$ channel (VSCC), $\mathrm{Na}^{+} / \mathrm{Ca}^{2+}$ exchanger and L-type voltage-sensitive $\mathrm{Ca}^{2+}$ channels (L-type VSCC) for $\mathrm{Li}^{+}$uptake was tested using tetrodotoxin (TTX), $\omega$-CgTx GVIA, KB-R7943 and nifendipine, respectively. The effect of protein kinase $\mathrm{A}$ (PKA) and of the intracellular free $\mathrm{Ca}^{2+}$ concentration $\left(\left[\mathrm{Ca}^{2+}\right]_{\mathrm{i}}\right)$ was also tested, using KT-5720 (PKA inhibitor) and BAPTA $\left(\mathrm{Ca}^{2+}\right.$ chelator), respectively. The concentrations used of $\omega$-CgTx GVIA and nifendipine were according to published data with (a)

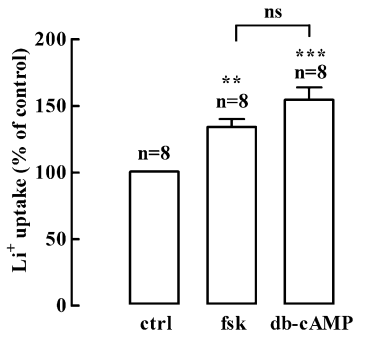

(b)

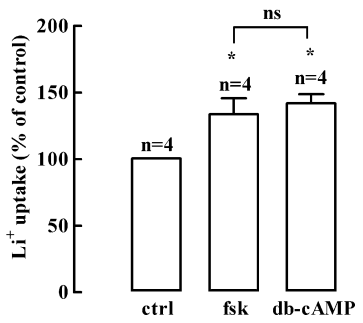

Fig. 2 Effect of fsk on $\mathrm{Li}^{+}$uptake by cortical (a) or hippocampal neurons (b). After preincubating the cells with RO-201724 $(25 \mu \mathrm{m})$, for $15 \mathrm{~min}$, they were pretreated or not (ctrl) with $10 \mu \mathrm{m}$ fsk (15 min) or $500 \mu \mathrm{M}$ db-cAMP (30 min) and later incubated with $1 \mathrm{~mm} \mathrm{LiCl}$ for $30 \mathrm{~min}$. The total amount of intracellular $\mathrm{Li}^{+}$was measured by $\mathrm{AA}$ spectrophotometry. Data are presented as a percentage of total intracellular $\mathrm{Li}^{+}$content relative to the control. Values are means \pm SEM, for the indicated number of independent experiments. ${ }^{*} p<0.05$; ${ }^{\star \star} p<0.01 ;{ }^{* \star \star} p<0.001$, significantly different from control; ns, not significant. 


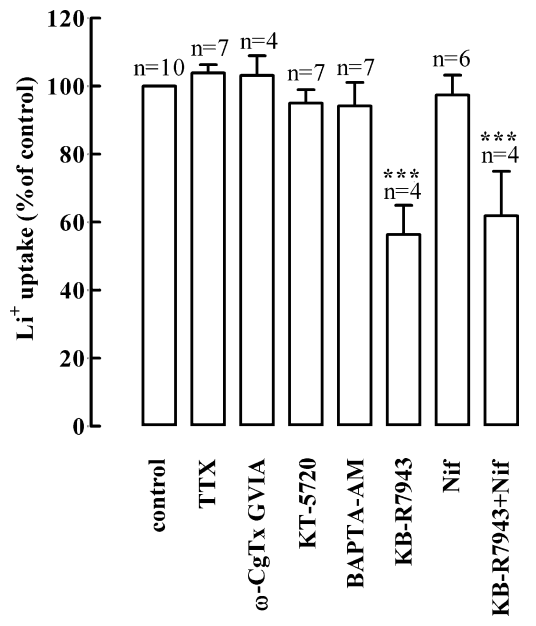

Fig. 3 Pharmacological characterization of $\mathrm{Li}^{+}$uptake by $\mathrm{SH}-\mathrm{SY} 5 \mathrm{Y}$ cells under resting conditions. The cells were pretreated with RO$201724(25 \mu \mathrm{M})$, for $15 \mathrm{~min}$, and then with the following drugs, at different concentrations and preincubation times: TTX (1 $\mu \mathrm{M} ; 5 \mathrm{~min})$, $\omega$-CgTx GVIA (0.5 $\mu \mathrm{m} ; 30 \mathrm{~min}), \mathrm{KT}-5720$ (10 $\mu \mathrm{m} ; 10 \mathrm{~min})$, BAPTA-AM

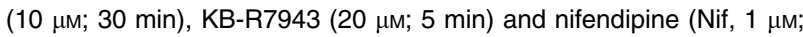
$5 \mathrm{~min}$ ), to study the contribution of VSSC, N-type VSCC, PKA, $\left[\mathrm{Ca}^{2+}\right]_{\text {i }}$, $\mathrm{Na}^{+} / \mathrm{Ca}^{2+}$ exchanger and L-type VSCC, respectively. $\mathrm{LiCl}$ at $1 \mathrm{~mm}$ concentration was added to the medium and at $30 \mathrm{~min}$ the amount of $\mathrm{Li}^{+}$taken up by cells was measured by AA spectrophotometry. Total intracellular $\mathrm{Li}^{+}$content is presented as a percentage relative to the control. Values are means \pm SEM, for the indicated number of independent experiments. ${ }^{\star \star \star} p<0.01$, significantly different from control.

undifferentiated SH-SY5Y cells (Reeve et al. 1994; Hirota and Lambert 1997). The other drugs were used at a concentration that produces a maximal effect under our experimental conditions (data not shown).

Figure 3 shows that under resting conditions the $\mathrm{Na}^{+} / \mathrm{Ca}^{2+}$ exchanger is the main transport pathway responsible for $\mathrm{Li}^{+}$ influx, as there was a significant decrease in $\mathrm{Li}^{+}$uptake in the presence of KB-R7943 relative to the control $(56.4 \pm 8.6 \%$; $p<0.001)$. None of the other inhibitors tested affected $\mathrm{Li}^{+}$ uptake by SH-SY5Y cells under resting conditions.

Similar experiments were performed using cells preincubated with forskolin in order to determine the identity of the transport pathway(s) responsible for the increase in $\mathrm{Li}^{+}$ uptake induced by intracellular accumulation of cAMP (Fig. 4a,b). The increase of $\mathrm{Li}^{+}$uptake observed under forskolin stimulation $(126.9 \pm 11.6 \%)$ was most significantly reduced by inhibition of the $\mathrm{Na}^{+} / \mathrm{Ca}^{2+}$ exchanger $(50.4 \pm 7.3 \% ; p<0.001)$, as shown in Fig. 4(b), indicating that this transport system plays the most relevant role in $\mathrm{Li}^{+}$ uptake. Under the same conditions, it was observed that the increase in $\mathrm{Li}^{+}$uptake was also significantly reduced in the presence of KT-5720 (97.5 $\pm 11.2 \% ; p<0.01), \omega$-CgTx GVIA $(88.1 \pm 9.2 \% ; p<0.001)$ and BAPTA $(86.3 \pm 4.6 \%$; $p<0.001)$, whereas nifendipine $(107.4 \pm 6.9 \% ; \mathrm{p}>0.05)$ and TTX $(118.1 \pm 2.0 \% ; p>0.05)$ did not affect significantly (a)

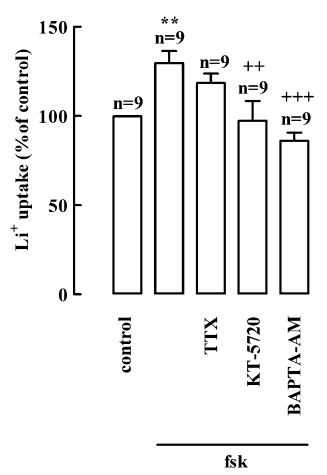

(b)

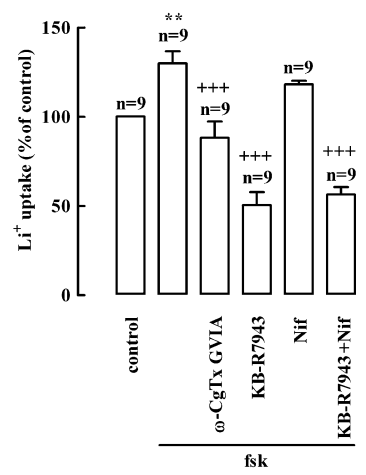

Fig. 4 Pharmacological characterization of $\mathrm{Li}^{+}$uptake by $\mathrm{SH}-\mathrm{SY} 5 \mathrm{Y}$ cells incubated with fsk. The cells were pretreated with RO-201724 $(25 \mu \mathrm{M})$, for $15 \mathrm{~min}$, and the contribution of VSSC, PKA and $\left[\mathrm{Ca}^{2+}\right]_{i}$ to the fsk-induced $\mathrm{Li}^{+}$uptake was studied by using TTX ( $1 \mu \mathrm{M}$; preincubation during $5 \mathrm{~min}$ ), KT-5720 (10 $\mu \mathrm{M}$; preincubation during $10 \mathrm{~min}$ ) and BAPTA-AM (10 $\mu \mathrm{M}$; preincubation during $30 \mathrm{~min})$, respectively (a). The contribution of the $\mathrm{N}$ - and L-type VSCC, and of the $\mathrm{Na}^{+} / \mathrm{Ca}^{2+}$ exchanger, to the fsk-induced increase in $\mathrm{Li}^{+}$uptake was investigated using $\omega$-CgTx GVIA (0.5 $\mu \mathrm{m}$; preincubation during $30 \mathrm{~min})$, Nif ( $1 \mu \mathrm{m}$; preincubation during $5 \mathrm{~min}$ ) and KB-R7943 (20 $\mu \mathrm{M}$; preincubation during $5 \mathrm{~min}$ ), respectively (b). After exposure to the drugs, the cells were incubated with fsk $(10 \mu \mathrm{m})$, for $15 \mathrm{~min}$, and then $1 \mathrm{~mm} \mathrm{LiCl}$ was added to the medium. At 30 min the amount of $\mathrm{Li}^{+}$taken up by the cells was measured by AA spectrophotometry. Total intracellular $\mathrm{Li}^{+}$ content is presented as a percentage relative to the control. Values are means $\pm S E M$, for the indicated number of independent experiments. ${ }^{* *} p<0.01$, significantly different from control; ${ }^{++} p<0.01$; ${ }^{++} p<0.001$, significantly different from fsk stimulation in the absence of any of these drugs.

the accumulation of $\mathrm{Li}^{+}$(Fig. 4a,b). Under both resting and stimulating conditions, the uptake of $\mathrm{Li}^{+}$by cells incubated simultaneously with KB-R7943 and nifendipine (61.9 \pm $13.0 \%$ under basal conditions and $56.3 \pm 4.1 \%$ after forskolin stimulation) was not significantly different from that observed in the presence of KB-R7943 alone $(56.4 \pm 8.6 \%$ for basal conditions and $50.4 \pm 7.3 \%$ for forskolin) (Figs 3 and $4 \mathrm{~b})$.

\section{Determination of $\left[\mathrm{Ca}^{2+}\right]_{\mathrm{i}}$}

As interference with the $\mathrm{Ca}^{2+}$ homeostasis mechanism affected $\mathrm{Li}^{+}$uptake, $\left[\mathrm{Ca}^{2+}\right]_{\mathrm{i}}$ was measured under the experimental conditions used in the $\mathrm{Li}^{+}$studies, using the $\mathrm{Ca}^{2+}$ sensitive fluorescence probe fura-2 (Grynkiewicz et al. 1985). The experiments were carried out under resting conditions (Fig. 5a) and upon forskolin stimulation (Fig. 5b), using the same inhibitors and blockers employed in the study of $\mathrm{Li}^{+}$influx pathways.

The results in Fig. 5(a) show that the inhibitors used did not affect the resting $\left[\mathrm{Ca}^{2+}\right]_{\mathrm{i}}(78.0 \pm 5.5 \mathrm{nM})$, except KBR7943, which increased significantly $\left[\mathrm{Ca}^{2+}\right]_{\mathrm{i}}(106.9 \pm$ $3.8 \mathrm{~nm} ; \quad p<0.01)$. The $\left[\mathrm{Ca}^{2+}\right]$ increase after forskolin 
(a)

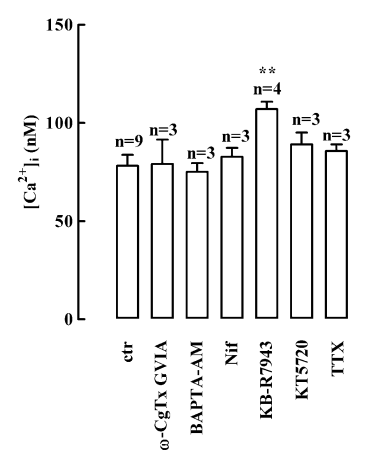

(b)

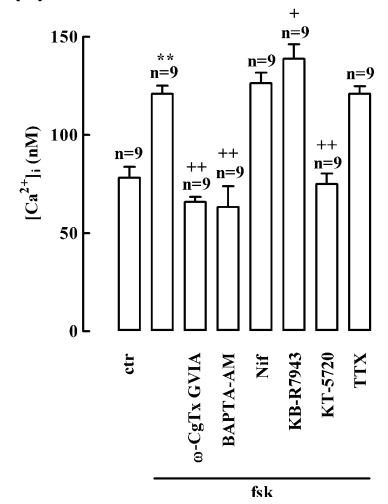

(a)

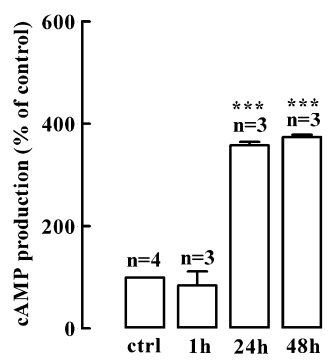

(c) (b)

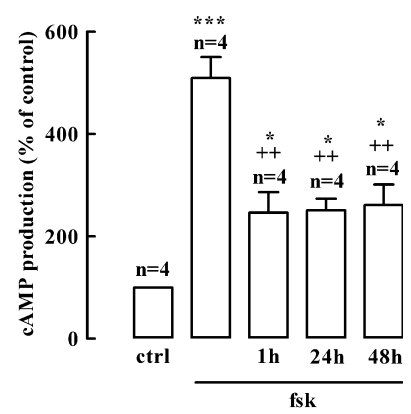

Fig. 5 Pharmacological characterization of the pathways for $\left[\mathrm{Ca}^{2+}\right]_{\mathrm{i}}$ homeostasis in SH-SY5Y cells under resting conditions (a) and after stimulation with fsk (b). Cells were pretreated with RO-201724 $(25 \mu \mathrm{M})$, for $15 \mathrm{~min}$, and then with $\omega$-CgTx GVIA $(0.5 \mu \mathrm{m}$; preincubation during $30 \mathrm{~min}$ ), Nif ( $1 \mu \mathrm{m}$; preincubation during $5 \mathrm{~min}$ ), KB-R7943 (20 $\mu \mathrm{M}$; preincubation during $5 \mathrm{~min}$ ), KT-5720 (10 $\mu \mathrm{m}$; preincubation during $10 \mathrm{~min}$ ) or TTX (1 $\mu \mathrm{m}$; preincubation during $5 \mathrm{~min}$ ), to test the contribution of $\mathrm{N}$ - and L-type VSCC, $\mathrm{Na}^{+} / \mathrm{Ca}^{2+}$ exchanger, PKA and VSSC, respectively, to the maintenance of the $\left[\mathrm{Ca}^{2+}\right]_{i}$. The effect of the $\mathrm{Ca}^{2+}$ chelator, BAPTA, was also determined by preincubating the cells with $10 \mu \mathrm{M}$ BAPTA-AM, for $30 \mathrm{~min}$. The cells were stimulated or not with $10 \mu \mathrm{m}$ fsk, for $15 \mathrm{~min}$, and the $\left[\mathrm{Ca}^{2+}\right]_{i}$ was measured by fluorescence spectroscopy using fura-2. Values are means \pm SEM, for the indicated number of independent experiments. ${ }^{* *} p<0.01$; significantly different from control; ${ }^{+} p<0.05 ;{ }^{++} p<0.01$, significantly different from fsk stimulation in the absence of any drug.

stimulation was inhibited in the presence of KT-5720 $(74.9 \pm 5.3 \mathrm{~nm} ; p<0.01), \omega$-CgTx GVIA $(65.8 \pm 2.6 \mathrm{~nm}$; $p<0.01)$ or BAPTA $(63.2 \pm 10.6 \mathrm{~nm} ; p<0.01)$ (Fig. $5 \mathrm{~b})$. In contrast, inhibition of the $\mathrm{Na}^{+} / \mathrm{Ca}^{2+}$ exchanger with KB-R7943 further increased the $\left[\mathrm{Ca}^{2+}\right]_{\mathrm{i}}$ in cells stimulated with forskolin $(138.6 \pm 7.4 \mathrm{~nm} ; p<0.05)$, whereas nifendipine and TTX were without effect.

\section{Determination of intracellular cAMP levels}

The results of Figs 1, 2 and 4 show that cAMP levels affect $\mathrm{Li}^{+}$uptake. We then investigated whether $\mathrm{Li}^{+}$taken up by SH-SY5Y cells modulates cAMP production, using a radioactive biochemical assay. Figure 6 shows the intracellular cAMP content under control conditions and the effect of exposure to $1 \mathrm{~mm}$ of $\mathrm{Li}^{+}$during 1,24 and $48 \mathrm{~h}$, under basal conditions (Fig. 6a) and after forskolin stimulation (Fig. 6b). Exposure of the cells to $\mathrm{Li}^{+}$, for $1 \mathrm{~h}$, did not affect cAMP levels when compared to the control $(84.7 \pm 27.0 \%$; $p>0.05)$, but longer incubations with $\mathrm{Li}^{+}$increased the cAMP content in a time-dependent manner $(4 \mathrm{~h}$, $152.2 \pm 38.4 \% ; 6 \mathrm{~h}, 198.9 \pm 8.3 \% ; 10 \mathrm{~h}, 279.2 \pm 8.3 \%$ ) (data not shown) and a maximal effect was obtained after $24 \mathrm{~h}$ incubation with $\mathrm{Li}^{+}(358.2 \pm 6.9 \% ; p<0.001)$. This

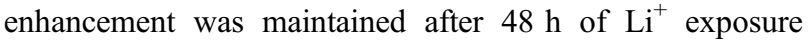

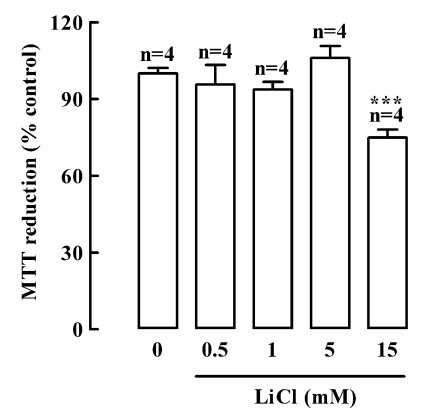

Fig. 6 Effects of $\mathrm{Li}^{+}$on cAMP production by SH-SY5Y cells. (a) Cells were pretreated with RO-201724 $(25 \mu \mathrm{M})$, for $15 \mathrm{~min}$, and then incubated or not (ctrl) with $1 \mathrm{mM} \mathrm{Li}^{+}$, for the indicated periods of time. (b) Where indicated, the cells were stimulated with $10 \mu \mathrm{m}$ fsk, for $15 \mathrm{~min}$, after treatment with $\mathrm{Li}^{+}$. The cAMP levels were measured as described in the methods section. (c) MTT biochemical assay with SH-SY5Y cells treated with $\mathrm{LiCl}(0,0.5,1,5$ and $15 \mathrm{~mm})$, during a period of $48 \mathrm{~h}$. Data are presented as a percentage relative to the control. Values are means \pm SEM, for the indicated number of independent experiments. ${ }^{*} p<0.05 ;{ }^{* \star *} p<0.001$, significantly different from the control. ${ }^{++} p<0.01$, significantly different from fsk stimulation in the absence of $\mathrm{Li}^{+}$.

$(374.5 \pm 4.6 \%, p<0.001)$ (Fig. 6a). As expected, forskolin stimulation significantly increased intracellular cAMP levels relative to the control $(509.2 \pm 40.9 \% ; p<0.001)$, and this effect was partially inhibited in cells pre-exposed to $\mathrm{Li}^{+}$for $1 \mathrm{~h}(246.1 \pm 40.4 \% ; p<0.01)$. Similar results were obtained in cells incubated with $\mathrm{Li}^{+}$for $24 \mathrm{~h}(250.0 \pm 22.9 \%$; $p<0.01)$ or $48 \mathrm{~h}(261.0 \pm 40.3 \% ; p<0.01)$ (Fig. 6b).

In order to check the metabolic and physiological conditions of SH-SY5Y cells in these experiments, cell

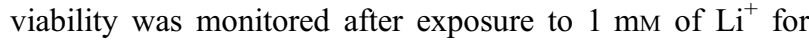
$48 \mathrm{~h}$. Figure 6(c) shows that no significant changes in viability relative to the control were observed when the cells

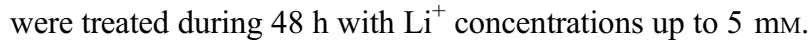

\section{Discussion}

The present study demonstrates that activation of AC with forskolin increases $\mathrm{Li}^{+}$uptake by $\mathrm{SH}-\mathrm{SY} 5 \mathrm{Y}$ cells and by 
cultured hippocampal and cortical neurons, at therapeutic concentrations of the cation. The effect of cAMP in SHSY5Y cells was mediated by PKA and occurred via changes in the $\left[\mathrm{Ca}^{2+}\right]_{\mathrm{i}}$. Accordingly, intracellular accumulation of cAMP increased the $\left[\mathrm{Ca}^{2+}\right]_{i}$ due to $\mathrm{Ca}^{2+}$ entry through N-type VSCC, and inhibition of these channels with $\omega$-CgTx GVIA also inhibited the effect of cAMP on $\mathrm{Li}^{+}$uptake. SHSY5Y cells used in the present work as a neuronal model are electrically excitable and express VSSC (Forsythe et al. 1992), L- and N-type VSCC (Lambert et al. 1990; Reeve et al. 1994; Hirota and Lambert 1997), and the $\mathrm{Na}^{+} / \mathrm{Ca}^{2+}$ exchanger (Nakamura et al. 2000).

Under resting conditions the uptake of $\mathrm{Li}^{+}$by SH-SY5Y cells was partially inhibited (about $40 \%$ ) by the $\mathrm{Na}^{+} / \mathrm{Ca}^{2+}$ exchanger inhibitor KB-R7943, indicating that in nonstimulated cells, $\mathrm{Li}^{+}$influx is accompanied by the efflux of $\mathrm{Ca}^{2+}$. This role of the $\mathrm{Na}^{+} / \mathrm{Ca}^{2+}$ exchanger in the maintenance of the $\left[\mathrm{Ca}^{2+}\right]_{\mathrm{i}}$ in control cells is supported by the results showing an increase of the $\left[\mathrm{Ca}^{2+}\right]_{\mathrm{i}}$ in the presence of the inhibitor of the antiporter. A similar effect of KB-R7943 on the $\left[\mathrm{Ca}^{2+}\right]_{i}$ under resting conditions was previously reported in cardiomyocytes (Iwamoto et al. 1996). In agreement with the present findings, $\mathrm{Li}^{+}$has been shown to replace $\mathrm{Na}^{+}$in many exchange pathways (Beaugé 1978; Pandey et al. 1978; Sarkadi et al. 1978; Ehrlich and Diamond 1980; Busch et al. 1995; Layden et al. 2003), including the $\mathrm{Na}^{+} / \mathrm{Ca}^{2+}$ antiporter (Abajo et al. 1987; De la Fuente et al. 1996; Deval and Cognard 2002; Fonseca et al. 2004). A fraction of $\mathrm{Li}^{+}$uptake by SH-SY5Y cells, under resting conditions and after forskolin stimulation, was insensitive to the $\mathrm{Na}^{+} / \mathrm{Ca}^{2+}$ exchanger inhibitor. The remaining contribution probably arises from a leak, which represents passive permeation through pores in the membrane (Ehrlich and Diamond 1980). As expected, inhibition of N- and L-type VSCC and of VSSC was without effect on $\mathrm{Li}^{+}$uptake under resting conditions, indicating that these pathways do not contribute to the influx of the cation in non-stimulated conditions.

Forskolin stimulation increased the $\mathrm{Li}^{+}$influx rate constant, $k_{\mathrm{i}}$, in SH-SY5Y cells, indicating that cAMP activates $\mathrm{Li}^{+}$transport pathways that are not involved in the transport of the cation under resting conditions. The $\mathrm{Ca}^{2+}$ chelator BAPTA inhibited forskolin-induced $\mathrm{Li}^{+}$uptake, and was without effect on the accumulation of $\mathrm{Li}^{+}$under resting conditions, indicating that the transport pathway activated by cAMP is dependent on a rise in the $\left[\mathrm{Ca}^{2+}\right]_{\mathrm{i}}$. Because $\omega$-CgTx GVIA, a N-type VSCC blocker, inhibited the accumulation of $\mathrm{Li}^{+}$induced by forskolin, $\mathrm{Ca}^{2+}$ influx through these channels is likely to be involved in the activation of the $\mathrm{Li}^{+}$ uptake pathway. VSCC are not permeable to $\mathrm{Li}^{+}$(Corry et al. 2001) and therefore the forskolin-induced $\mathrm{Li}^{+}$uptake must be secondary to the $\left[\mathrm{Ca}^{2+}\right]_{\mathrm{i}}$ rise due to activation of $\mathrm{N}$-type VSCC. In contrast to the role of N-type VSCC in the uptake of $\mathrm{Li}^{+}$induced by cAMP, inhibition of L-type VSCC did not affect $\mathrm{Li}^{+}$uptake by $\mathrm{SH}-\mathrm{SY} 5 \mathrm{Y}$ cells after stimulation with forskolin. Although undifferentiated SH-SY5Y cells express both L- and N-type VSCC (Lambert et al. 1990; Reeve et al. 1994; Hirota and Lambert 1997) the latter are predominantly expressed and play a major role in $\mathrm{Ca}^{2+}$ entry (Seward and Henderson 1990; Forsythe et al. 1992; Reuveny and Narahashi 1993). This may explain the differences observed in their relative role in $\mathrm{Li}^{+}$uptake under our experimental conditions.

As previously stated, the effect of forskolin on the uptake of $\mathrm{Li}^{+}$and on the $\left[\mathrm{Ca}^{2+}\right]_{\mathrm{i}}$ was inhibited by the PKA inhibitor, KT5720 , which is in agreement with evidences indicating that PKA is the most important target of cAMP (Skalhegg and Tasken 2000). PKA is known to phosphorylate several neuronal proteins, including ion channels (Scott 1991; Walaas and Greengard 1991; Spaulding 1993). Accordingly, cAMP increasing agents have been shown to activate $\mathrm{Na}^{+}$influx currents through non-selective cation channels, insensitive to TTX, thereby depolarizing the cells and leading to the activation of N- and L-type VSCC (Holz et al. 1995; Kato et al. 1996; Takano et al. 1996; Leech and Habener 1998; Miura and Matsui 2003). Although PKA may regulate the activity of VSCC by phosphorylation (Gross et al. 1990; Ahlijanian et al. 1991; Meuth et al. 2002), this effect requires membrane depolarization to activate the channels. Therefore, phosphorylation of VSCC by PKA cannot account directly for the increased $\mathrm{Ca}^{2+}$ influx observed in forskolin stimulated cells, which causes a rise of intracellular $\mathrm{Li}^{+}$transport.

Low concentrations of KB-R7943 $(0.3-10 \mu \mathrm{M})$ inhibit preferentially the reverse mode of the $\mathrm{Na}^{+} / \mathrm{Ca}^{2+}$ transporter, and higher concentrations $(30 \mu \mathrm{M})$ are required to reduce the forward mode of the exchanger (Iwamoto et al. 1996). At the concentration used in the present study $(20 \mu \mathrm{M})$ KB-R7943 decreased $\mathrm{Li}^{+}$uptake by SH-SY5Y cells, under resting conditions and following stimulation of $\mathrm{AC}$, to about the same levels. These results indicate that $\mathrm{Li}^{+}$is taken up by the $\mathrm{Na}^{+} / \mathrm{Ca}^{2+}$ antiporter, most likely in exchange with intracellular $\mathrm{Ca}^{2+}$. Furthermore, the results show that activation of the $\mathrm{Na}^{+} / \mathrm{Ca}^{2+}$ exchanger fully accounts for the up-regulation of $\mathrm{Li}^{+}$uptake in cells exposed to forskolin. This is probably due to the $\left[\mathrm{Ca}^{2+}\right]_{\mathrm{i}}$ rise induced by cAMP, which is likely to activate the $\mathrm{Na}^{+} / \mathrm{Ca}^{2+}\left(\mathrm{Li}^{+} / \mathrm{Ca}^{2+}\right)$ exchanger in order to extrude the $\mathrm{Ca}^{2+}$ taken up by the cells. Although the $\mathrm{Na}^{+}$/ $\mathrm{Ca}^{2+}$ exchanger has a low-affinity for $\mathrm{Ca}^{2+}$ it has a high capacity of transport, thereby contributing to $\left[\mathrm{Ca}^{2+}\right]_{\mathrm{i}}$ buffering (Matsuda et al. 1997). KB-R7943 may also reduce the activity of VSSC and L-type VSCC (Iwamoto et al. 1996), but this does not account for the observed effects on $\mathrm{Li}^{+}$ uptake as specific inhibition of the channels with TTX and nifendipine, respectively, had minor effects on the transport of the cation under our experimental conditions. However, it was shown that stimulation of VSSC with veratridine causes an increase on $\mathrm{Li}^{+}$influx apparent rate constant in SH-SY5Y cells and this effect was completely reverted by TTX (Nikolakopoulos et al. 1998). 
Stimulation of SH-SY5Y cells with forskolin increased the $\left[\mathrm{Ca}^{2+}\right]_{\mathrm{i}}$, in agreement with previous findings in GT1-7 cells (Kaneishi et al. 2002), somatotropes (Holl et al. 1989) and in myocytes (Xiong et al. 2001). The effect of intracellular accumulation of cAMP on the $\left[\mathrm{Ca}^{2+}\right]_{i}$ was reduced in the presence of KT-5720, indicating that it is mediated by PKA activation. Pre-incubation of the cells with the N-type VSCC blocker also inhibited the effect of forskolin on the $\left[\mathrm{Ca}^{2+}\right]_{\mathrm{i}}$, indicating that PKA activation somehow leads to the depolarization of the membrane and activation of $\mathrm{Ca}^{2+}$ channels. In contrast, inhibition of L-type VSCC was without effect on forskolin-induced $\left[\mathrm{Ca}^{2+}\right]_{\mathrm{i}}$ rise, indicating that N-type VSCC was selectively recruited. Because TTX was also without effect on the $\left[\mathrm{Ca}^{2+}\right]_{\mathrm{i}}$ response to forskolin, the effect was not mediated by activation of VSSC sensitive to the toxin. Inhibition of the $\mathrm{Na}^{+} / \mathrm{Ca}^{2+}$ exchanger during the period of stimulation with forskolin further increased the $\left[\mathrm{Ca}^{2+}\right]_{\text {i }}$, indicating that $\mathrm{Ca}^{2+}$ taken up by the cells through N-type VSCC is extruded by the antiporter.

In SH-SY5Y cells treated with $1 \mathrm{~mm}$ of $\mathrm{Li}^{+}$the observed decrease in forskolin-induced cAMP production demonstrates the inhibitory effect of $\mathrm{Li}^{+}$on $\mathrm{AC}$ at therapeutic concentrations. These results confirm previous in vitro studies showing that $\mathrm{Li}^{+}$inhibits forskolin-stimulated AC activity (Newman and Belmaker 1987; Mørk and Geisler 1989a). Forskolin is thought to interact directly with the catalytic unit of AC (Bender and Neer 1983; Seamon 1981). Moreover, it is well known that $\mathrm{Mg}^{2+}$ is essential for the activity of this enzyme (Sulakhe and Hoehn 1984). As $\mathrm{Li}^{+}$and $\mathrm{Mg}^{2+}$ have similar physicochemical properties (Frausto da Silva and Williams 1976), $\mathrm{Li}^{+}$may interfere with the modulatory effect of $\mathrm{Mg}^{2+}$ by competing for $\mathrm{Mg}^{2+}$ binding sites in biomolecules (Mørk and Geisler 1987a; Ramasamy et al. 1989; Mota de Freitas et al. 1994; Layden et al. 2000; Ryves and Harwood 2001). This effect may explain the inhibitory effect of $\mathrm{Li}^{+}$observed in the present study. Although $\mathrm{Li}^{+}$was shown to activate phosphodiesterase (Smith 1990), this does not account for the observed decrease in cAMP levels, as a selective inhibitor of phosphodiesterase 4 was used (Reeves et al. 1987). This phosphodiesterase isoform is expressed in SH-SY5Y cells and plays a major role in cAMP hydrolysis (Jang and Juhnn 2001).

The increase in basal cAMP levels after $1 \mathrm{mM} \mathrm{Li}^{+}$ treatment at incubation times longer than $1 \mathrm{~h}$ is consistent with results from in vitro and ex vivo experiments (Ebstein et al. 1980; Newman and Belmaker 1987), as well as with in vivo microdialysis studies (Masana et al. 1991; Masana et al. 1992). The increase of cAMP basal levels by $\mathrm{Li}^{+}$has been attributed to inhibition of $G_{i}$, which is the G-protein preferentially activated under basal conditions (Jope 1999b; Brunello and Tascedda 2003). In resting conditions $1 \mathrm{~h}$ may not be enough to inhibit $G_{i}$ leading to the increase in cAMP. However, a progressive increase in cAMP levels with time was observed until a maximal value was reached at $24 \mathrm{~h}$, which was then maintained until $48 \mathrm{~h}$. Under basal conditions cAMP levels at 24 and $48 \mathrm{~h}$ of incubation with $\mathrm{Li}^{+}$were not significantly different from those obtained after forskolin stimulation for the same $\mathrm{Li}^{+}$incubation periods, thus suggesting a total inhibitory effect of $\mathrm{Li}^{+}$on the stimulation of AC by forskolin.

Taken together, our results indicate that cAMP regulates $\mathrm{Li}^{+}$uptake and intracellular $\mathrm{Li}^{+}$also controls AC activity. This suggests that under basal conditions, cAMP levels are low leading to a low $\mathrm{Li}^{+}$influx. Once $\mathrm{Li}^{+}$is inside the cells it might raise cAMP levels thereby promoting its own influx. When cAMP production is up-regulated, $\mathrm{Li}^{+}$influx is increased and may then reduce the stimulated production of cAMP. Overall, the inhibitory effect of $\mathrm{Li}^{+}$on $\mathrm{G}_{\mathrm{i}}$, which results in elevated basal levels of cAMP, and the attenuation of forskolin-induced increases in cAMP production, by direct interaction with the catalytic unit of $\mathrm{AC}$, may reduce the magnitude of fluctuations in cAMP levels. The present results are in agreement with the stabilizing effect of $\mathrm{Li}^{+}$in the homeostasis of intracellular cAMP in SH-SY5Y cells. The present study also suggests that the mechanism of mood stabilizing effects of $\mathrm{Li}^{+}$is not due to a selective interference with any particular neurotransmitter system, but rather affects the functional balance between interacting systems (Masana et al. 1992; Manji et al. 1995; Jope 1999a; Jope 1999b).

Preclinical and clinical studies suggest that the pathophysiological basis of bipolar disorder involves disturbances in the cAMP signal transduction system and that the mood-stabilizing agent, $\mathrm{Li}^{+}$interferes with this pathway (Chang et al. 2003). It is also known that $\mathrm{Ca}^{2+}$ (in micromolar concentrations) stimulates some AC isoforms through calmodulin (Lakey et al. 1985; Tang et al. 1991) indicating that there is a cross-talk between $\mathrm{Ca}^{2+}$ regulatory and cAMP signaling systems. As disturbances in both G-protein mediated cAMP and $\mathrm{Ca}^{2+}$-signaling have been reported in bipolar disease (Emamghoreishi et al. 2000), cross-talk regulatory mechanisms are potentially important candidates to explain abnormalities in these two signal transduction pathways. Thus, increased $\left[\mathrm{Ca}^{2+}\right]_{\mathrm{i}}$ reported in bipolar disorder might result from altered G-protein function, also identified in these patients, or vice versa. Additionally, it was found that $\mathrm{Li}^{+}$ bipolar responders have a higher $\left[\mathrm{Ca}^{2+}\right]_{\mathrm{i}}$ than patients with normal calcium levels, which indicates a correlation between intracellular $\mathrm{Ca}^{2+}$ levels and lithium response (Ikeda and Kato 2003).

Our studies demonstrate a direct correlation between stimulated increase of intracellular cAMP levels, increased $\left[\mathrm{Ca}^{2+}\right]_{\mathrm{i}}$ and increase of $\mathrm{Li}^{+}$uptake by neuronal cells, which may contribute to a better understanding of the mechanism of $\mathrm{Li}^{+}$action in the treatment of bipolar disorder.

\section{Acknowledgements}

The authors acknowledge financial support from Fundação para a Ciência e a Tecnologia (FCT), Portugal (Project POCTI/1999/BCI/ 
36160), FEDER and NIMH (grant number MH-45926 to D. Mota de Freitas). Liliana P. Montezinho and Carla P. Fonseca were supported by FCT grants, SFRH/BD/3286/2000 and Praxis XXI/ $\mathrm{BD} / 21462 / 99$, respectively. The authors are thankful to Professor Helena Freitas from the Botany Department, for the facilities in using the AA spectrophotometer and to Drs M. João Bastos and Helena Castro for helping in the AA measurements. The authors are grateful to Drs Sandra Almeida and Inês Araújo for their assistance in the preparation of cortical and hippocampal cultures, respectively.

\section{References}

Abajo F. J., Castro M. A., Garijo B. and Sanchez-Garcia P. (1987) Catecholamine release evoked by lithium from the perfused adrenal gland of the cat. Br. J. Pharmacol. 91, 539-546.

Ahlijanian M. K., Striessnig J. and Catterall W. A. (1991) Phosphorylation of an alpha 1-like subunit of an omega-conotoxin-sensitive brain calcium channel by cAMP-dependent protein kinase and protein kinase. J. Biol. Chem. 266, 20192-20197.

Allison J. H. and Stewart M. A. (1971) Reduced brain inositol in lithiumtreated rats. Nat. New Biol. 233, 267-268.

Amari L., Layden B., Nikolakopoulos J., Rong Q., Mota de Freitas D., Baltazar G., Castro M. M. and Geraldes C. F. (1999) Competition between $\mathrm{Li}^{+}$and $\mathrm{Mg}^{2+}$ in neuroblastoma SH-SY5Y cells: a fluorescence and ${ }^{31} \mathrm{P}$ NMR study. Biophys. J. 76, 2934-2942.

Andersen P. H. and Geisler A. (1984) Lithium inhibition of forskolinstimulated adenylate cyclase. Neuropsychobiology 12, 1-3.

Avissar S., Schreiber G., Danon A. and Belmaker R. H. (1988) Lithium inhibits adrenergic and cholinergic increases in GTP binding in rat cortex. Nature 331, 440-442.

Beaugé L. (1978) Activation by lithium ions of the inside sodium sites in $\left(\mathrm{Na}^{+}-\mathrm{K}^{+}\right)$-ATPase. Biochim. Biophys. Acta 527, 472-484.

Bender J. L. and Neer E. J. (1983) Properties of the adenylate cyclase catalytic unit from caudate nucleus. J. Biol. Chem. 258, 24322439 .

Brewer G. J., Torricelli J. R., Evege E. K. and Price P. J. (1993) Optimized survival of hippocampal neurons in B27-supplemented neurobasal, a new serum-free medium combination. J. Neurosci. Res. 35, 567-576.

Brunello N. and Tascedda F. (2003) Cellular mechanisms and second messengers: relevance to the psychopharmacology of bipolar disorders. Int. J. Neuropsychopharmacol. 6, 181-189.

Busch S., Burckhardt B. C. and Siffert W. (1995) Expression of the human sodium/proton exchanger NHE-1 in Xenopus laevis oocytes enhances sodium/proton exchange activity and establishes sodium/ lithium countertransport. Pflugers Arch. 429, 859-869.

Carli M., Anand-Srivastava M. B., Molina-Holgado E., Dewar K. M. and Reader T. A. (1994) Effects of chronic lithium treatments on central dopaminergic receptor systems: $G$ proteins as possible targets. Neurochem. Int. 24, 13-22.

Chang A., Li P. P. and Warsh J. J. (2003) Altered cAMP-dependent protein kinase subunit immunolabeling in post-mortem brain from patients with bipolar affective disorder. J. Neurochem. 84, 781-791.

Corry B., Allen T. W., Kuyucak S. and Chung S. H. (2001) Mechanisms of permeation and selectivity in calcium channels. Biophys. J. 80, 195-214.

De la Fuente M. T., Maroto R., Esquerro E., Sanchez-Garcia P. and Garcia A. G. (1996) The actions of ouabain and lithium chloride on cytosolic $\mathrm{Ca}^{2+}$ in single chromaffin cells. Eur. J. Pharmacol. 306, 219-226.

Deval E., Raymond G. and Cognard C. (2002) $\mathrm{Na}^{+}-\mathrm{Ca}^{2+}$ exchange activity in rat skeletal myotubes: effect of lithium ions. Cell Calcium 31, 37-44.
Dousa T. and Hechter O. (1970) Lithium and brain adenylyl cyclase. Lancet 1, 834-835.

Ebstein R. P., Hermoni M. and Belmaker R. H. (1980) The effect of lithium on noradrenaline-induced cyclic AMP accumulation in rat brain: inhibition after chronic treatment and absence of supersensitivity. J. Pharmacol. Exp. Ther. 213, 161-167.

Ehrlich B. E. and Diamond J. M. (1980) Lithium, membranes, and manic-depressive illness. J. Membr. Biol. 52, 187-200.

Emamghoreishi M., Li P. P., Schlichter L., Parikh S. V., Cooke R. and Warsh J. J. (2000) Associated disturbances in calcium homeostasis and $\mathrm{G}$ protein-mediated cAMP signalling in bipolar I disorder. Biol. Psychiatry 48, 665-673.

Fonseca C. P., Montezinho L. M., Nabais C., Tomé A. R., Freitas H., Geraldes C. F. G. C. and Castro M. M. C. A. (2004) Effect of $\mathrm{Li}^{+}$transport and intracellular binding on $\mathrm{Li}^{+} / \mathrm{Mg}^{2+}$ competition in bovine chromafin cells. BBA Mol. Cell Res. 1691, 79-90.

Forsythe I. D., Lambert D. G., Nahorski S. R. and Lindsdell P. (1992) Elevation of cytosolic calcium by cholinoceptor agonists in SH-SY5Y human neuroblastoma cells: estimation of the contribution of voltage-dependent currents. Br. J. Pharmacol. 107, 207-214.

Frausto da Silva J. J. and Williams R. J. (1976) Possible mechanism for the biological action of lithium. Nature 263, 237-239.

Friedman E. and Wang H. Y. (1996) Receptor-mediated activation of G proteins is increased in postmortem brains of bipolar affective disorder subjects. $J$. Neurochem. 67, 1145-1152.

Goodwin F. K. and Jamison K. R. (1990) Manic-Depressive Illness. New York: Oxford University Press.

Gross R. A., Moises H. C., Uhler M. D. and Macdonald R. L. (1990) Dynorphin A and cAMP-dependent protein kinase independently regulate neuronal calcium currents. Proc. Natl Acad. Sci. USA 87, $7025-7029$.

Grynkiewicz G., Poenie M. and Tsien R. Y. (1985) A new generation of $\mathrm{Ca}^{2+}$ indicators with greatly improved fluorescence properties. J. Biol. Chem. 260, 3440-3450.

Hallcher L. M. and Sherman W. R. (1980) The effects of lithium ion and other agents on the activity of myo-inositol-1-phosphatase from bovine brain. J. Biol. Chem. 255, 10896-10901.

Hertz E., Yua C. H., Hertz L., Jurlink B. H. J. and Schousboe A. (1989) Preparation of primary cultures of mouse cortical neurons, in $A$ Dissection and Tissue Culture Manual of the Nervous System (Shahar, A., de Vellis, J., Vernadakis, A. and Haber, B., eds). Alan R. Liss, New York.

Hirota K. and Lambert D. G. (1997) A comparative study of L-type voltage sensitive $\mathrm{Ca}^{2+}$ channels in rat brain regions and cultured neuronal cells. Neurosci. Lett. 223, 169-172.

Holl R. W., Thorner M. O. and Leong D. A. (1989) Cytosolic free calcium in normal somatotropes: effects of forskolin and phorbol ester. Am. J. Physiol. 256, E375-E379.

Holz G. G., Leech C. A. and Habener J. F. (1995) Activation of a cAMPregulated $\mathrm{Ca}^{2+}$-signalling pathway in pancreatic beta-cells by the insulinotropic hormone glucagon-like peptide-1. J. Biol. Chem. 270, 17749-17757.

Ikeda A. and Kato T. (2003) Biological predictors of lithium response in bipolar disorder. Psychiatry Clin. Neurosci. 57, 243-250.

Iwamoto T., Watano T. and Shigekawa M. (1996) A novel isothiourea derivative selectively inhibits the reverse mode of $\mathrm{Na}^{+} / \mathrm{Ca}^{2+}$ exchange in cells expressing NCX1. J. Biol. Chem. 271, 2239122397.

Jang I. S. and Juhnn Y. S. (2001) Adaptation of cAMP signaling system in SH-SY5Y neuroblastoma cells following expression of a constitutively active stimulatory G protein alpha, Q227L Gs $\alpha$. Exp. Mol. Med. 33, 37-45. 
Jope R. S. (1999a) Anti-bipolar therapy: mechanism of action of lithium. Mol. Psychiatry 4, 117-128.

Jope R. S. (1999b) A bimodal model of the mechanism of action of lithium. Mol. Psychiatry 4, 21-25.

Jope R. S. (2003) Lithium and GSK-3: one inhibitor, two inhibitory actions, multiple outcomes. Trends Pharmacol. Sci. 24, 441-443.

Kaneishi K., Sakuma Y., Kobayashi H. and Kato M. (2002) 3',5'-Cyclic adenosine monophosphate augments intracellular $\mathrm{Ca}^{2+}$ concentration and gonadotropin-releasing hormone $(\mathrm{GnRH})$ release in immortalized GnRH neurons in an $\mathrm{Na}^{+}$-dependent manner. Endocrinology 143, 4210-4217.

Kato M., Ma H. T. and Tatemoto K. (1996) GLP-1 depolarizes the rat pancreatic beta cell in a $\mathrm{Na}^{+}$-dependent manner. Regul. Pept. 62, $23-27$.

Lakey T., Mac N. S., Humphries H., Walker S. W., Munro D. S. and Tomlinson S. (1985) Calcium and calmodulin in the regulation of human thyroid adenylate cyclase activity. Biochem. J. 225, 581589.

Lambert D. G., Whitham E. M., Baird J. G. and Nahorski S. R. (1990) Different mechanisms of $\mathrm{Ca}^{2+}$ entry induced by depolarization and muscarinic receptor stimulation in SH-SY5Y human neuroblastoma cells. Brain Res. Mol. Brain Res. 8, 263-266.

Layden B., Diven C., Minadeo N., Bryant F. B. and Mota de Freitas D. (2000) $\mathrm{Li}^{+} / \mathrm{Mg}^{2+}$ competition at therapeutic intracellular $\mathrm{Li}^{+}$levels in human neuroblastoma SH-SY5Y cells. Bipolar Disord. 2, 200204.

Layden B. T., Abukhdeir A. M., Williams N., Fonseca C. P., Carroll L., Castro M. M., Geraldes C. F., Bryant F. B. and Mota de Freitas D. (2003) Effects of $\mathrm{Li}^{+}$transport and $\mathrm{Li}^{+}$immobilization on $\mathrm{Li}^{+} / \mathrm{Mg}^{2+}$ competition in cells: implications for bipolar disorder. Biochem. Pharmacol. 66, 1915-1924.

Leech C. A. and Habener J. F. (1998) A role for $\mathrm{Ca}^{2+}$-sensitive nonselective cation channels in regulating the membrane potential of pancreatic beta-cells. Diabetes 47, 1066-1073.

Manji H. K. (1992) G proteins: implications for psychiatry. Am. J. Psychiatry 149, 746-760.

Manji H. K., Potter W. Z. and Lenox R. H. (1995) Signal transduction pathways. Molecular targets for lithium's actions. Arch. Gen. Psychiatry 52, 531-543.

Masana M. I., Bitran J. A., Hsiao J. K., Mefford I. N. and Potter W. Z. (1991) Lithium effects on noradrenergic-linked adenylate cyclase activity in intact rat brain: an in vivo microdialysis study. Brain Res. 538, 333-336.

Masana M. I., Bitran J. A., Hsiao J. K. and Potter W. Z. (1992) In vivo evidence that lithium inactivates $G_{i}$ modulation of adenylate cyclase in brain. J. Neurochem. 59, 200-205.

Matsuda T., Takuma K. and Baba A. (1997) $\mathrm{Na}^{+}-\mathrm{Ca}^{2+}$ exchanger: physiology and pharmacology. Jpn. J. Pharmacol. 74, 1-20.

Meuth S., Pape H. C. and Budde T. (2002) Modulation of $\mathrm{Ca}^{2+}$ currents in rat thalamocortical relay neurons by activity and phosphorylation. Eur. J. Neurosci. 15, 1603-1614.

Miura Y. and Matsui H. (2003) Glucagon-like peptide-1 induces a cAMP-dependent increase of $\left[\mathrm{Na}^{+}\right]_{\mathrm{i}}$ associated with insulin secretion in pancreatic beta-cells. Am. J. Physiol. Endocrinol. Metab. 285, E1001-E1009.

Mørk A. and Geisler A. (1987a) Mode of action of lithium on the catalytic unit of adenylate cyclase from rat brain. Pharmacol. Toxicol. 60, 241-248.

Mørk A. and Geisler A. (1987b) Effects of lithium on calmodulin-stimulated adenylate cyclase activity in cortical membranes from rat brain. Pharmacol. Toxicol. 60, 17-23.

Mørk A. and Geisler A. (1989a) Effects of lithium ex vivo on the GTPmediated inhibition of calcium-stimulated adenylate cyclase activity in rat brain. Eur. J. Pharmacol. 168, 347-354.
Mørk A. and Geisler A. (1989b) The effects of lithium in vitro and ex vivo on adenylate cyclase in brain are exerted by distinct mechanisms. Neuropharmacology 28, 307-311.

Mørk A. and Geisler A. (1989c) Effects of GTP on hormone-stimulated adenylate cyclase activity in cerebral cortex, striatum, and hippocampus from rats treated chronically with lithium. Biol. Psychiatry 26, 279-288

Mosmann T. (1983) Rapid colorimetric assay for cellular growth and survival: application to proliferation and cytotoxicity assays. J. Immunol. Methods 65, 55-63.

Mota de Freitas D., Amari L., Srinivasan C., Rong Q., Ramasamy R., Abraha A., Geraldes C. F. and Boyd M. K. (1994) Competition between $\mathrm{Li}^{+}$and $\mathrm{Mg}^{2+}$ for the phosphate groups in the human erythrocyte membrane and ATP: an NMR and fluorescence study. Biochemistry 33, 4101-4110.

Nakamura H., Kawasaki Y., Arakawa N., Saeki M., Maeda S., Koyama Y., Baba A. and Matsuda T. (2000) The $\mathrm{Na}^{+}-\mathrm{Ca}^{2+}$ exchange inhibitor KB-R7943 inhibits high $\mathrm{K}^{+}$-induced increases in intracellular $\mathrm{Ca}^{2+}$ concentration and $\left[{ }^{3} \mathrm{H}\right]$-noradrenaline release in the human neuroblastoma SH-SY5Y. Neurochem. Res. 25, 385-387.

Newman M. E. and Belmaker R. H. (1987) Effects of lithium in vitro and ex vivo on components of the adenylate cyclase system in membranes from the cerebral cortex of the rat. Neuropharmacology $\mathbf{2 6}$, 211-217.

Newman M. E., Drummer D. and Lerer B. (1990) Single and combined effects of desimipramine and lithium on serotonergic receptor number and second messenger function in rat brain. J. Pharmacol. Exp. Ther. 252, 826-831.

Nikolakopoulos J., Zachariah C., Mota de Freitas D., Stubbs E. B. Jr, Ramasamy R., Castro M. C. and Geraldes C. F. (1998) ${ }^{7}$ Li nuclear magnetic resonance study for the determination of $\mathrm{Li}^{+}$properties in neuroblastoma SH-SY5Y cells. J. Neurochem. 71, 1676-1684.

Pandey G. N., Sarkadi B., Haas M., Gunn R. B., Davis J. M. and Tosteson D. C. (1978) Lithium transport pathways in human red blood cells. J. Gen. Physiol. 72, 233-247.

Ramasamy R. and Mota de Freitas D. (1989) Competition between $\mathrm{Li}^{+}$ and $\mathrm{Mg}^{2+}$ for ATP in human erythrocytes: ${ }^{31} \mathrm{P}$ NMR and optical spectroscopy study. FEBS Lett. 244, 223-226.

Reeve H. L., Vaughan P. F. and Peers C. (1994) Calcium channel currents in undifferentiated human neuroblastoma (SH-SY5Y) cells: actions and possible interactions of dihydropyridines and omegaconotoxin. Eur. J. Neurosci. 6, 943-952.

Reeves M. L., Leigh B. K. and England P. J. (1987) The identification of a new cyclic nucleotide phosphodiesterase activity in human and guinea-pig cardiac ventricle. Implications for the mechanism of action of selective phosphodiesterase inhibitors. Biochem. J. 241, 535-541.

Reuveny E. and Narahashi T. (1993) Two types of high voltage-activated calcium channels in SH-SY5Y human neuroblastoma cells. Brain Res. 603, 64-73.

Ryves W. J. and Harwood A. J. (2001) Lithium inhibits glycogen synthase kinase- 3 by competition for magnesium. Biochem. Biophys. Res. Commun. 280, 720-725.

Sarkadi B., Alifimoff J. K., Gunn R. B. and Tosteson D. C. (1978) Kinetics and stoichiometry of Na-dependent Li transport in human red blood cells. J. Gen. Physiol. 72, 249-265.

Scott J. D. (1991) Cyclic nucleotide-dependent protein kinases. Pharmacol. Ther. 50, 123-145.

Seamon K. B. and Daly J. W. (1981) Activation of adenylate cyclase by the diterpene forskolin does not require the guanine nucleotide regulatory protein. J. Biol. Chem. 256, 9799-9801.

Seward E. P. and Henderson G. (1990) Characterization of two components of the $\mathrm{N}$-like, high-threshold-activated calcium channel 
current in differentiated SH-SY5Y cells. Pflugers Arch. 417, 223 230.

Skalhegg B. S. and Tasken K. (2000) Specificity in the cAMP/PKA signalling pathway: differential expression, regulation, and subcellular localization of subunits of PKA. Front Biosci. 5, D678-D693.

Smith D. F. (1990) Effects of lithium and rolipram enantiomers on locomotor activity in inbred mice. Pharmacol. Toxicol. 66, 142145.

Spaulding S. W. (1993) The ways in which hormones change cyclic adenosine $3^{\prime}, 5^{\prime}$-monophosphate-dependent protein kinase subunits, and how such changes affect cell behavior. Endocr. Rev. 14, 632650.

Stubbs E. B. Jr. and Agranoff B. W. (1993) Lithium enhances muscarinic receptor-stimulated CDP-diacylglycerol formation in inositoldepleted SK-N-SH neuroblastoma cells. J. Neurochem. 60, 12921299.

Sulakhe P. V. and Hoehn E. K. (1984) Interaction of EGTA with a hydrophobic region inhibits particulate adenylate cyclase from rat cerebral cortex: a study of an EGTA-inhibitable enzyme by using alamethicin. Int. J. Biochem. 16, 1029-1035.
Takano K., Takei T., Teramoto A. and Yamashita N. (1996) GHRH activates a nonselective cation current in human GH-secreting adenoma cells. Am. J. Physiol. 270, E1050-E1057.

Tang W. J., Kuprinski J. and Gilman A. G. (1991) Expression and characterization of calmodulin-activated (type I) adenylyl-cyclase. J. Biol. Chem. 266, 8595-8603.

Walaas S. I. and Greengard P. (1991) Protein phosphorylation and neuronal function. Pharmacol. Rev. 43, 299-349.

Williams R. S. and Harwood A. J. (2000) Lithium therapy and signal transduction. Trends Pharmacol. Sci. 21, 61-64.

Xiong W., Moore H. M., Howlett S. E. and Ferrier G. R. (2001) In contrast to forskolin and 3-isobutyl-1-methylxanthine, amrinone stimulates the cardiac voltage-sensitive release mechanism without increasing calcium-induced calcium release. J. Pharmacol. Exp. Ther. 298, 954-963.

Young L. T., Li P. P., Kish S. J., Siu K. P., Kamble A., Hornykiewicz O. and Warsh J. J. (1993) Cerebral cortex $\mathrm{G}_{\mathrm{s}}$ alpha protein levels and forskolin-stimulated cyclic AMP formation are increased in bipolar affective disorder. J. Neurochem. 61, 890-898. 